
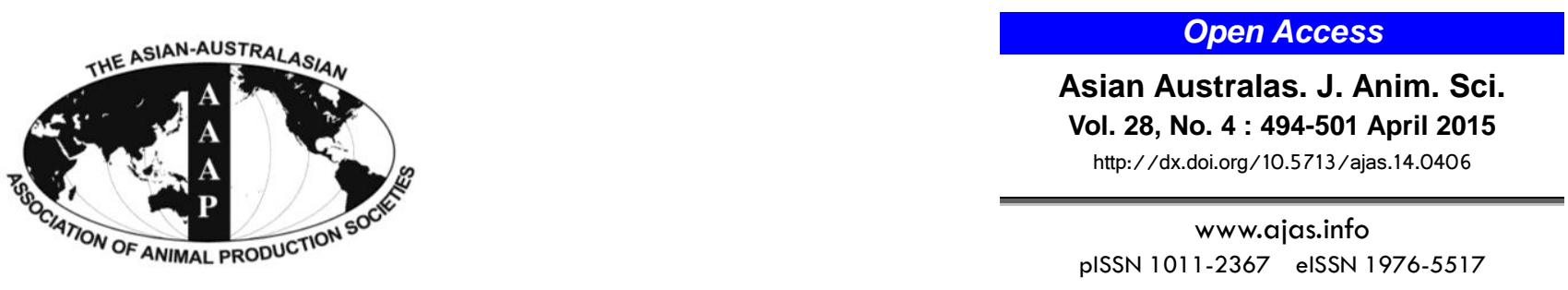

\title{
Effects of Supplementation of Mulberry (Morus alba) Foliage and Urea-rice Bran as Fermentable Energy and Protein Sources in Sheep Fed Urea-treated Rice Straw Based Diet
}

\author{
Dwi Yulistiani*, Z. A. Jelan ${ }^{1}$, J. B. Liang ${ }^{2}$, H. Yaakub ${ }^{1}$, and N. Abdullah ${ }^{2}$ \\ Indonesian Research Institute for Animal Production, Bogor 16002, Indonesia
}

\begin{abstract}
A digestibility study was conducted to evaluate the effects of supplementing mulberry foliage and urea rice-bran as a source of fermentable energy and protein to 12 sheep fed diets based on urea-treated rice straw (TRS). The three dietary treatments were: T1, TRS with mulberry; T2, TRS with 50\% mulberry replaced with rice bran and urea; and T3, TRS with rice bran and urea. The study was arranged in a completely randomized design with four replications for each treatment. The sheep were fed one of the three diets and the supplements were offered at $1.2 \%$ of the body weight (BW) and the TRS was provided ad libitum. There were no differences ( $>0.05$ ) among the three treatment groups with respect to dry matter (DM) intake $\left(76.8 \pm 4.2 \mathrm{~g} / \mathrm{kg} \mathrm{BW}^{0.75}\right.$ ) and DM, organic matter $(\mathrm{OM})$, and crude protein (CP) digestibility $(55.3 \pm 1.22 ; 69.9 \pm 0.85 ; 46.3 \pm 1.65 \%$ respectively for DM, OM, and CP). The digestibility of fiber (neutral detergent fiber $[\mathrm{NDF}]$ and acid detergent fiber) was significantly lower ( $<0.05$ ) for T3 (46.2 and 46.6 respectively) compared to T1 (55.8 and 53.7 respectively) and T2 (54.1 and 52.8 respectively). Nitrogen (N) intake by sheep on diet T3 was significantly $(\mathrm{p}<0.05)$ higher than sheep fed diet T1. However, $\mathrm{N}$ balance did not differ among the three diets $(3.0 \pm 0.32 \mathrm{~g} / \mathrm{d})$. In contrast, the rumen ammonia $\left(\mathrm{NH}_{3}-\mathrm{N}\right)$ concentrations in sheep fed $\mathrm{T} 2$ and $\mathrm{T} 3$ were significantly $(\mathrm{p}<0.05)$ higher than in sheep fed $\mathrm{T} 1$. The $\mathrm{NH}_{3}-\mathrm{N}$ concentrations for all three diets were above the critical value required for optimum rumen microbial growth and synthesis. Total volatile fatty acid concentrations were highest $(\mathrm{p}<0.05)$ in $\mathrm{T} 1(120.3 \mathrm{mM})$, whilst the molar proportion of propionic acid was highest in $\mathrm{T} 3$ $(36.9 \%)$. However, the microbial $\mathrm{N}$ supply in sheep fed $\mathrm{T} 1$ and $\mathrm{T} 3$ was similar but was significantly $(\mathrm{p}<0.05)$ higher than for sheep fed T2. It was concluded that mulberry foliage is a potential supplement of fermentable energy and protein for sheep fed TRS based diet. The suggested level of supplementation is $1.2 \%$ of BW or $32 \%$ of the total diet since it resulted in similar effects on the intake of DM, $\mathrm{OM}$, and NDF, digestibility of DM, OM, and CP, N utilization and microbial supply when compared to rice bran and urea supplementation. (Key Words: Mulberry (Morus alba), Fermentable Energy, Fermentable Protein, Feed Supplementation, Sheep)
\end{abstract}

\section{INTRODUCTION}

Crop residues and agricultural by-products are important feeds for ruminants in developing countries as the priority of land is used for food crops instead of fodder production. Rice straw (RS) is still abundantly available in rice production areas and is commonly used as feed for all

\footnotetext{
* Corresponding Author: Dwi Yulistiani. Tel: +62-2518328384, Fax: +62-2518240754, E-mail: dwiyulistiani@yahoo.com

1 Department of Animal Science, Faculty of Agriculture, Universiti Putra Malaysia, Serdang, Selangor 43400, Malaysia.

${ }^{2}$ Institute of Tropical Agriculture, Universiti Putra Malaysia, Serdang, Selangor 43400, Malaysia.

Submitted May 28, 2014; Revised Aug. 17, 2014; Accepted Oct. 8, 2014
}

classes of ruminants. Inherent low nutritive values of RS limit its utilization by rumen microorganisms and consequently by the host animal. Treating RS with urea can be a routine practice, safe to use, provides a source of inorganic nitrogen $(\mathrm{N})$ that is deficient in RS (Van Soest, 2006) and increases the fiber degradation in the rumen (Yulistiani et al., 2011). Although the digestibility of ureatreated rice straw (TRS) has been shown to be improved when fed as a sole diet to sheep, the animals showed negative $\mathrm{N}$ balance and lost body weight (BW) due to low voluntary feed intake (Elseed, 2004). An adequate and sustained provision of $\mathrm{N}$ to the rumen microbes are crucial for optimum plant cell digestion and a high microbial protein synthesis (MPS). Supplementation with concentrate 
feed to improve the utilization of low quality roughages is a normal practice, but is often not economically feasible to smallholder farmers. Utilizing tree foliages with high crude protein $(\mathrm{CP})$ content is a cheaper alternative.

Mulberry foliage has high CP content and degradability and is considered as a high value supplement of fermentable energy for ruminants consuming low quality roughages (Saddul et al., 2005; Yulistiani et al., 2008). Therefore, feeding mulberry foliage can promote a favorable condition for plant cell wall degrading microorganisms in the rumen. Previous studies have emphasized the feeding of mulberry foliage as a source of protein to animals on low quality roughage such as RS (Huyen et al., 2012) or ammoniated RS (Liu et al., 2001). However, the utilization of mulberry foliage as a source of both fermentable energy and protein for ruminant is generally limited. Results from a study utilising in vitro gas production technique of various diets indicated that the optimum combination of TRS and mulberry diet was in the ratio of 60:40 with an addition of $5 \%$ molasses to increase digestibility of the basal diet and production of propionic acid (Yulistiani et al., 2007).

This study was conducted to evaluate the potential of mulberry foliage as sources of fermentable energy and protein in sheep fed TRS based diets through the measurements of nutrient utilization, volatile fatty acids (VFAs) production and microbial protein yield.

\section{MATERIALS AND METHODS}

\section{Preparation of feeds}

Preparation of urea-treated rice straw : Approximately 1 metric ton of dry RS was obtained from rice fields and chopped into size of approximately $5 \mathrm{~cm}$. The RS was treated by spraying $5 \%$ urea solution $(1 \mathrm{~L} / \mathrm{kg}$ dry matter [DM] straw), then thoroughly mixed and placed in black plastic bag. The air was removed by careful trampling of the bag ( $5 \mathrm{~kg}$ treated straw/bag). The bags were tightly sealed and stored for three weeks. After the treatment duration, the treated straw was evenly spread on a concrete floor for a day to allow the excess ammonia to evaporate before feeding to the sheep.

Preparation of mulberry foliage : After allowing 6 weeks of re-growth, leaves were harvested from an approximately 0.5 ha plot of established mulberry trees at the experimental farm of the Department of Animal Science, Universiti Putra Malaysia, Serdang, Selangor, Malaysia. The harvested foliage was chopped to approximately $5 \mathrm{~cm}$ size and dried under the sun for 3 days. At this stage the DM content of the mulberry was approximately $90 \%$. Sufficient chopped and dried foliage was made, thoroughly mixed and stored for use in the study.

\section{Animals, dietary treatments and experimental design}

A digestibility study was conducted using 12 mature (2 years of age) indigenous Malin rams with an average BW of $19.8 \pm 1.4 \mathrm{~kg}$. The animals were divided into three groups in a completely randomized design and were placed in individual metabolic crate during the experimental period.

All sheep were fed a basal diet of TRS with supplements. The three treatment groups were as follows: $\mathrm{T} 1=\mathrm{TRS}+$ mulberry; $\mathrm{T} 2=\mathrm{TRS}+50 \%$ mulberry replacement with urea-rice bran mixture and $\mathrm{T} 3=$ TRS+urea-rice bran mixture. Molasses at 5\% of DM TRS was supplemented to all diets and mixed to TRS to improve straw palatability.

The diets were formulated to be iso-nitrogenous and iso-energetic (containing a calculated $\mathrm{CP}$ content of $11.4 \%$ and $8.3 \mathrm{MJ} \mathrm{ME} / \mathrm{kg} \mathrm{DM}$ ). The sheep were initially fed with the supplements until completely consumed and then followed with TRS that was offered ad libitum. Drinking water and commercial mineral licks were freely available to the animals.

The chemical composition of feed ingredients used in the diet is presented in Table 1 and the ingredients and chemical compositions of the three dietary treatments are shown in Table 2.

\section{Digestibility trial}

The digestibility trial consisted of 14 days of adaptation period, 7 days for sample collection and 1 day for sampling of ruminal fluid. During the collection period, daily feed intake and refusal, and fecal and urine output of the individual sheep were measured. Urine and fecal samples were separated by the separator attached below each metabolic crate. Daily fecal output was collected from individual sheep before their morning feeding. Each representative portion ( $10 \%$ from total fecal production) of fecal sample was oven-dried at $60^{\circ} \mathrm{C}$ for $48 \mathrm{~h}$. At the end of the collection period, the feces were pooled for individual sheep and a $10 \%$ sub-sample, ground through $1 \mathrm{~mm}$ sieve and stored in the freezer pending analyses.

Total daily urine excretion of each sheep was collected in a bucket containing $100 \mathrm{~mL}$ of $10 \%$ sulfuric acid (to maintain $\mathrm{pH}$ below 3 for inhibiting microbial activity and $\mathrm{N}$ losses). The samples were collected every morning and after recording the volume, the urine was mixed thoroughly.

Table 1. Ingredients and chemical composition of feed used in the formulation of the experimental diets

\begin{tabular}{lccccc}
\hline \multirow{2}{*}{$\begin{array}{l}\text { Feed } \\
\text { ingredients }\end{array}$} & \multicolumn{5}{c}{ Chemical composition (\% DM) } \\
\cline { 2 - 6 } TRS & DM & OM & CP & NDF & ADF \\
Mulberry foliage & 93.2 & 88.4 & 6.5 & 71.8 & 57.3 \\
Molasses & 66.0 & 92.0 & 19.6 & 49.5 & 29.5 \\
Urea $(\mathrm{N} \times 6.25)$ & - & 94.3 & 5.8 & - & - \\
Rice bran & 87.5 & 92.0 & 11.1 & 27.7 & 8.9 \\
\hline
\end{tabular}

DM, dry matter; OM, organic matter; $\mathrm{CP}$, crude protein; NDF, neutral detergent fiber; $\mathrm{ADF}$, acid detergent fiber; TRS, urea treated rice straw. 
Table 2. Composition of supplements and calculated chemical composition of the supplements

\begin{tabular}{lccc}
\hline \multirow{2}{*}{ Items } & \multicolumn{3}{c}{ Diets $^{1}$} \\
\cline { 2 - 4 } & $\mathrm{T} 1$ & $\mathrm{~T} 2$ & $\mathrm{~T} 3$ \\
\hline Feed ingredients & & & \\
$\quad$ Mulberry foliage (\%) & 38.1 & 19.1 & 0 \\
$\quad$ Urea (\%) & 0 & 0.7 & 1.3 \\
$\quad$ Rice bran (\%) & 0 & 18.3 & 36.8 \\
Calculated chemical composition & & & \\
Energy (ME MJ/kg) & 10.3 & 10.0 & 10.1 \\
CP (\%) & 19.6 & 20.4 & 20.5 \\
DM (\%) & 89 & 88.8 & 87.5 \\
OM (\%) & 92.0 & 90.3 & 92.0 \\
NDF (\%) & 49.5 & 38.1 & 27.7 \\
ADF (\%) & 29.5 & 19.0 & 8.9 \\
\hline ME,
\end{tabular}

ME, metabolisable energy; $\mathrm{CP}$, crude protein; DM, dry matter; OM, organic matter; NDF, neutral detergent fiber; ADF, acid detergent fiber

${ }^{1} \mathrm{~T} 1=$ mulberry foliage; $\mathrm{T} 2=50 \%$ of mulberry foliage was replaced with urea-rice bran mixture; $\mathrm{T} 3=$ mulberry foliage was totally replaced with urea-rice bran mixture.

Treated rice straw was offered ad libitum and mixed with molasses

A representative sample $10 \%$ of total urine was collected and kept in a freezer and pooled for each sheep at the end of collection period for analyses of urine- $\mathrm{N}$ and purine derivatives excretion.

On the final day of digestibility trial, ruminal fluid was collected from each sheep $4 \mathrm{~h}$ after their morning feeding using a stomach tube. Ruminal fluid $\mathrm{pH}$ was measured immediately after sampling using a portable $\mathrm{pH}$ meter. One drop of concentrated sulfuric acid was then added (to halt microbial activity) and the ruminal fluid was later centrifuged at 3,000 g for $10 \mathrm{~min}$. Approximately $10 \mathrm{~mL}$ of the supernatant was kept in air tight container and stored at $-20^{\circ} \mathrm{C}$ pending analyses for ammonia $\left(\mathrm{NH}_{3}-\mathrm{N}\right)$ concentration and VFA concentration and proportions.

\section{Chemical analyses}

Feeds, residues and feces were analyzed for DM, organic matter (OM), and $\mathrm{CP}$ contents according to the procedures of AOAC (1990). The fiber component (neutral detergent fiber $[\mathrm{NDF}]$ and acid detergent fiber [ADF]) were determined according to the procedures of Van Soest et al. (1991). Rumen $\mathrm{NH}_{3}-\mathrm{N}$ concentrations were determined by steam distillation and titration method. The concentration of total and individual VFA was determined according to the procedure of Cottyn and Bouque (1968). Purine derivatives (PD); allantoin, uric acid, xanthine, and hypoxanthine contents in the urine were determined using HPLC according to the method of Balcells et al. (1992). The PD was quantified in single run using allopurinol as an internal standard. Microbial-N production was estimated based on PD excretion using the equation of Chen and Gomez (1992) as follows:

\section{Microbial-N production $(\mathrm{g} \mathrm{N} / \mathrm{d})=0.727 \mathrm{x}$}

Where, $\mathrm{x}=$ microbial $\mathrm{PD}$ absorbed $(\mathrm{Mm} / \mathrm{d})$ after duodenal and intestinal digestion.

$$
\begin{aligned}
& \text { Urinary PD output }=0.84 \mathrm{x}+\left(0.15 \mathrm{w}^{0.75} \mathrm{e}^{-0.25 \mathrm{x}}\right) \\
& \text { Where } \mathrm{w} \text { is the weight of sheep. }
\end{aligned}
$$

\section{Statistical analyses}

Data were analyzed using general linear model for completely randomized design (SAS, 1989) and the significant differences among means of the different treatments were compared using Duncan's multiple range tests. Significance was taken at $\mathrm{p}<0.05$.

\section{RESULTS}

\section{Nutrient intake and digestion}

Total intake and apparent digestibility of nutrients in sheep fed the different diets are given in Table 3. There were no significant $(\mathrm{p}>0.05)$ differences among treatments except for the intake of $\mathrm{CP}$. Intake of $\mathrm{CP}$ by $\mathrm{T} 3$ sheep was significantly $(\mathrm{p}<0.05)$ higher than for $\mathrm{T} 1$ and $\mathrm{T} 2$. The intake of TRS was unaffected $(p>0.05)$ by the dietary treatments, with TRS intake accounting for $69 \%$ of the total DM intake. The digestibility of DM, OM, and CP was similar across the

Table 3. Mean nutrient intake and digestibility in sheep on the experimental diets

\begin{tabular}{lcccc}
\hline \multirow{2}{*}{ Parameters } & \multicolumn{3}{c}{ Diets $^{1}$} \\
\cline { 2 - 4 } & T1 & T2 & T3 \\
\hline Intake & & & & \\
$\quad$ Total DM (g/d) & 727.8 & 768.3 & 773.2 & 38.8 \\
OM (g/d) & 650.5 & 685.7 & 690.3 & 34.0 \\
CP (g/d) & $63.0^{\mathrm{b}}$ & $69.7^{\mathrm{b}}$ & $81.9^{\mathrm{a}}$ & 2.65 \\
NDF (g/d) & 486.8 & 482.2 & 426.5 & 24.9 \\
ADF (g/d) & 365.1 & 371.0 & 335.7 & 19.6 \\
TRS (\% of total DMI) & 66.4 & 71.0 & 68.6 & 2.22 \\
DMI as \% BW & 3.5 & 3.9 & 3.5 & 0.2 \\
DMI g/BW ${ }^{0.75}$ & 74.1 & 81.6 & 74.7 & 4.15 \\
Digestibility (\%) & & & & \\
DM & 54.0 & 56.4 & 55.6 & 0.82 \\
OM & 69.0 & 70.3 & 70.6 & 1.04 \\
CP & 44.8 & 48.1 & 46.2 & 1.75 \\
NDF & $55.8^{\mathrm{a}}$ & $54.1^{\mathrm{a}}$ & $46.2^{\mathrm{b}}$ & 1.16 \\
ADF & $53.7^{\mathrm{a}}$ & $52.8^{\mathrm{a}}$ & $46.6^{\mathrm{b}}$ & 1.36 \\
\hline
\end{tabular}

SEM, Standard error of mean; DMI, dry matter intake; OM, organic matter; CP, crude protein; NDF, neutral detergent fiber; ADF, acid detergent fiber; TRS, urea treated rice straw; BW, body weight; DM, dry matter.

${ }^{1} \mathrm{~T} 1=$ mulberry foliage; $\mathrm{T} 2=50 \%$ of mulberry foliage was replaced with urea-rice bran mixture; $\mathrm{T} 3=$ urea-rice bran mixture.

Means with different superscript in the same row are significantly different $(\mathrm{p}<0.05)$. 
Table 4. Mean values of $\mathrm{N}$ utilization in sheep fed the different experimental diets

\begin{tabular}{lcccc}
\hline \multirow{2}{*}{ Parameters } & \multicolumn{3}{c}{ Diets $^{1}$} & \multirow{2}{*}{ SEM } \\
\cline { 2 - 4 } & $\mathrm{T} 1$ & $\mathrm{~T} 2$ & $\mathrm{~T} 3$ & \\
\hline Intake $(\mathrm{g} / \mathrm{d})$ & $11.1^{\mathrm{b}}$ & $11.7^{\mathrm{ab}}$ & $13.0^{\mathrm{a}}$ & 0.46 \\
$\mathrm{~N}$ excretion & & & & \\
$\quad$ Fecal N (g/d) & $5.7^{\mathrm{b}}$ & $5.6^{\mathrm{b}}$ & $7.2^{\mathrm{a}}$ & 0.41 \\
$\quad$ Fecal N (\% of intake) & 51.3 & 48.5 & 55.7 & 2.55 \\
$\quad$ Urinary N (g/d) & 2.0 & 3.2 & 2.8 & 0.43 \\
$\quad$ Urinary N (\% of intake) & 18.5 & 28.1 & 22.1 & 4.17 \\
N absorption (g/d) & 5.4 & 6.0 & 5.7 & 0.36 \\
N balance (g/d) & 3.3 & 2.8 & 2.8 & 0.61 \\
N balance (\% of intake) & 28.8 & 21.0 & 20.0 & 4.80 \\
\hline
\end{tabular}

SEM, standard error of mean; $\mathrm{N}$, nitrogen.

${ }^{1} \mathrm{~T} 1=$ mulberry foliage; $\mathrm{T} 2=50 \%$ of mulberry foliage was replaced with urea-rice bran mixture; $\mathrm{T} 3=$ urea-rice bran mixture.

Means with different superscript in the same row are significantly different $(\mathrm{p}<0.05)$.

three treatments. Fiber (NDF and ADF) digestibility was significantly $(\mathrm{p}<0.05)$ lower for $\mathrm{T} 3$ compared to $\mathrm{T} 1$ and $\mathrm{T} 2$.

\section{Nitrogen utilization}

The utilization of $\mathrm{N}$ in sheep fed the different diets is shown in Table 4. Daily N intake was significantly $(\mathrm{p}<0.05)$ higher for sheep fed T3 compared to those fed T1. Fecal N from animals fed diet $\mathrm{T} 3$ was significantly $(\mathrm{p}<0.05)$ higher than those fed either T1 or T2. However, urinary $\mathrm{N}$ and $\mathrm{N}$ balance were similar across all three treatments, with sheep in all treatment groups having a positive $\mathrm{N}$ balance, indicating an adequate level of $\mathrm{N}$ in the diets.

\section{Rumen fermentation}

Mean values of rumen $\mathrm{pH}$, rumen $\mathrm{NH}_{3}-\mathrm{N}$ concentrations

Table 5. Mean rumen $\mathrm{pH}, \mathrm{NH}_{3}-\mathrm{N}$ concentration, total and proportion of VFA in sheep fed the different experimental diets

\begin{tabular}{lcccc}
\hline \multirow{2}{*}{ Parameters } & \multicolumn{3}{c}{ Diets $^{1}$} & \multirow{2}{*}{ SEM } \\
\cline { 2 - 4 } & $\mathrm{T} 1$ & $\mathrm{~T} 2$ & $\mathrm{~T} 3$ & \\
\hline Rumen pH & 6.8 & 6.8 & 6.7 & 0.04 \\
Rumen $\mathrm{NH}_{3}-\mathrm{N}(\mathrm{mg} / \mathrm{dL})$ & $17.8^{\mathrm{b}}$ & $21.8^{\mathrm{a}}$ & $23.0^{\mathrm{a}}$ & 1.48 \\
Total VFA (Mm) & $120.3^{\mathrm{a}}$ & $106.6^{\mathrm{b}}$ & $105.9^{\mathrm{b}}$ & 3.47 \\
Molar proportion (\%) & & & & \\
$\quad$ Acetic & $58.6^{\mathrm{a}}$ & $56.1^{\mathrm{a}}$ & $49.0^{\mathrm{b}}$ & 1.27 \\
$\quad$ Propionic & $28.2^{\mathrm{b}}$ & $28.0^{\mathrm{b}}$ & $36.9^{\mathrm{a}}$ & 1.54 \\
Iso-butyric & 1.03 & 0.95 & 1.13 & 1.44 \\
Butyric & $10.1^{\mathrm{b}}$ & $13.1^{\mathrm{a}}$ & $11.0^{\mathrm{b}}$ & 0.80 \\
Iso-valeric & 0.94 & 0.74 & 0.64 & 0.13 \\
$\quad$ Valeric & 1.15 & 1.09 & 1.30 & 0.21 \\
Acetic/propionic & 2.2 & 2.06 & 1.40 & 0.15 \\
\hline
\end{tabular}

VFA, volatile fatty acid; SEM, standard error of mean; $\mathrm{NH}_{3}-\mathrm{N}$, ammonia nitrogen.

${ }^{1} \mathrm{~T} 1=$ mulberry foliage; $\mathrm{T} 2=50 \%$ of mulberry foliage was replaced with urea-rice bran mixture; $\mathrm{T} 3=$ urea-rice bran mixture.

Means with different superscript in the same row are significantly different $(\mathrm{p}<0.05)$. and total VFA concentrations and proportions are presented in Table 5. The average rumen $\mathrm{pH}$ was 6.8 and was unaffected $(p>0.05)$ by the different dietary supplements. On the other hand, rumen $\mathrm{NH}_{3}-\mathrm{N}$ concentrations differed among treatments where sheep fed $\mathrm{T} 2$ and $\mathrm{T} 3$ had significantly $(\mathrm{p}<0.05)$ higher rumen $\mathrm{NH}_{3}-\mathrm{N}$ concentrations than those fed T1. Total VFA concentrations were significantly $(\mathrm{p}<0.05)$ higher in sheep fed T1 compared to those fed either $\mathrm{T} 2$ or $\mathrm{T} 3$. The proportion of acetic acid was significantly $(\mathrm{p}<0.05)$ lower and the proportion of propionic acid significantly higher $(\mathrm{p}<0.05)$ in sheep fed $\mathrm{T} 3$ compared to those fed either T1 or T2 . The molar proportions of other VFA (butyric, iso-butyric, valeric, iso-valeric) and the ratio of acetic:propionic were similar across the dietary treatments.

\section{Urinary purine derivatives and estimation of microbial nitrogen supply}

Urinary PD excretion (allantoin and uric acid) did not differ $(p>0.05)$ between the dietary treatments (Table 6). Similarly, the proportions of each purine derivative were also unaffected $(p>0.05)$ by the different dietary supplementations. Microbial N supply (MNS) was lower $(\mathrm{p}<0.05)$ for $\mathrm{T} 2$ compared toT1 and $\mathrm{T} 3$.

\section{DISCUSSION}

\section{Nutrient intake and digestion}

In the feeding trial, TRS was offered ad libitum, but the supplements were offered at $1.2 \% \mathrm{BW}$. This was carried out to study the effect of different dietary supplementations on TRS intake. Previously, Yulistiani et al. (2008) reported that $\mathrm{CP}, \mathrm{DM}$, and $\mathrm{OM}$ of mulberry were highly degradable in the rumen and therefore could be used as sources of rumen degradable protein (RDP) and fermentable carbohydrate in the diet of ruminants. The non-sisgnificant of TRS intake among diet treatments indicating that TRS based diet supplemented with RDP either from mulberry or urea, and fermentable carbohydrate either from mulberry, molasses or rice bran did not result in reduction of TRS intake. According to Melaku et al. (2004), feeding a supplement to overcome protein and mineral deficiency could increase intake of low quality forage. However, in this study, supplementation of either mulberry foliage (T1) or mulberry foliage replaced partially (T2) or totally (T3) with urea rice bran mixture did not increase the intake of TRS. Similarly, Kozloski et al. (2007) reported supplementation with both cassava meal and casein or cassava meal and urea as source of fermentable carbohydrate and fermentable $\mathrm{N}$ resulted in similar dry matter intake (DMI). On the other hand, Melaku et al. (2004) reported that supplementation of Sesbania and Leucaena mixture increased the intake of straw by sheep. The variations in straw intake are due to the 
Table 6. Excretion of urinary purine derivative (PD) and estimated daily microbial nitrogen supply (MNS) in sheep fed the different experimental diets

\begin{tabular}{|c|c|c|c|c|}
\hline \multirow{2}{*}{ Parameters } & \multicolumn{3}{|c|}{ Diets $^{1}$} & \multirow{2}{*}{ SEM } \\
\hline & $\mathrm{T} 1$ & $\mathrm{~T} 2$ & T3 & \\
\hline \multicolumn{5}{|l|}{ Purine derivative excretion $(\mathrm{Mm} / \mathrm{d})$} \\
\hline Allantoin & 10.2 & 8.6 & 10.4 & 0.388 \\
\hline Uric acid & 1.29 & 1.19 & 0.94 & 0.073 \\
\hline Hypoxantine and Xantine & $0.61^{\mathrm{ab}}$ & $0.72^{\mathrm{a}}$ & $0.37^{\mathrm{b}}$ & 0.036 \\
\hline Total & 12.1 & 9.5 & 11.7 & 0.325 \\
\hline Purine derivative excretion $\left(\mathrm{Mm} / \mathrm{W}^{075} / \mathrm{d}\right)$ & 1.17 & 1.09 & 1.04 & 0.038 \\
\hline \multicolumn{5}{|l|}{ Proportion of purine derivative excretion } \\
\hline Allantoin & 0.83 & 0.82 & 0.88 & 0.82 \\
\hline Uric acid & 0.11 & 0.11 & 0.87 & 0.67 \\
\hline Hypoxantine and xantine & 0.06 & 0.07 & 0.04 & 0.38 \\
\hline DOMI (kg/d) & 0.60 & 0.63 & 0.64 & 0.07 \\
\hline DOMR (kg/d) & 0.39 & 0.41 & 0.42 & 0.02 \\
\hline MNS (g N/d) & $14.4^{\mathrm{a}}$ & $8.8^{\mathrm{b}}$ & $13.2^{\mathrm{a}}$ & 1.32 \\
\hline
\end{tabular}

SEM, standard error of mean; DOMI, digestible organic matter intake; DOMR, digestible organic matter fermented in the rumen.

$\mathrm{T} 1=$ mulberry foliage; $\mathrm{T} 2=50 \%$ of mulberry foliage was replaced with urea-rice bran mixture; $\mathrm{T} 3=$ urea-rice bran mixture.

Means with different superscript in the same row are significantly different $(\mathrm{p}<0.05)$.

nature of both protein and energy supplements. Similar to total TRS intake, the digestibility of DM, OM, and CP was not affected by the different dietary supplementations.

The digestibility of fiber (NDF and ADF) was significantly lower for T3 compared to T1 and T2 (Table 3). The negative effect of supplementing large amounts of readily fermentable carbohydrate on fiber digestibility has been previously reported (Kosloski et al., 2007). This study indicated that the digestibility of NDF and ADF decreased when mulberry was totally replaced by urea-rice bran mixture at a proportion of about $30 \%$ from the total intake (Table 3). According to Mlay et al. (2003), there was no effect of different sources of fermentable protein [non protein nitrogen, NPN] or true protein) on fiber digestibility of hay. In the present study, the $\mathrm{N}$ source in $\mathrm{T} 3$ was from urea. Since the fermentable protein content in the three supplements was similar and sufficient, the decreased fibre digestibility of T3 seemed to be associated with the source of fermentable energy from rice bran which has a greater effect on fiber digestibility than urea. The higher fermentable energy from rice bran in the dietary treatment $\mathrm{T} 3$ probably caused the competition of $\mathrm{N}$ utilization among the fibrolytic bacteria and amylolytic bacteria. According to Heldt et al. (1999a), the higher fermentable energy in the starch allows amylolytic bacteria to rapidly ferment more starch. As a result, $\mathrm{N}$ utilization by amylolytic bacteria is increased and consequently, $\mathrm{N}$ availability for fibrolytic bacteria is decreased, which in turn reduces the fibrolytic activity (Martin et al., 2001), leading to low fiber digestibility.

The higher fiber digestibility of $\mathrm{T} 2$ and $\mathrm{T} 1$ than $\mathrm{T} 3$ indicated that the fermentable energy from mulberry in the form of fiber with sufficient rumen degradable $\mathrm{N}$ or protein from either urea or mulberry in $\mathrm{T} 2$ and $\mathrm{T} 1$, respectively were able to produce higher fiber digestibility. According to Heldt et al. (1999b), when RDP is sufficient, the supplementation of fermentable energy in the form of fiber results in higher fiber digestibility.

\section{Nitrogen utilization}

The fecal $\mathrm{N}$ excretion was higher in sheep fed $\mathrm{T} 3$, although NPN (urea) was simultaneously supplemented with fermentable energy (rice bran) in the diet. The higher fecal $\mathrm{N}$ was most probably due to the higher hindgut fermentation which resulted in higher microbial $\mathrm{N}$ production. Mlay et al. (2003) reported that cattle fed low quality hay supplemented with fermentable energy and urea had lower fiber digestibility in the rumen, but higher hindgut fermentation which increased fecal $\mathrm{N}$ from microbial production. In the present study the urinary $\mathrm{N}$ excretion was comparable among the three dietary treatments. This indicated that ammonia production from the hydrolysis of urea (T2 and T3) was utilized for microbial synthesis as efficiently as $\mathrm{N}$ from mulberry supplementation (in $\mathrm{T} 1$ ). Neither urinary $\mathrm{N}$ or $\mathrm{N}$ balance differed among dietary treatments. Retention of $\mathrm{N}$ is considered as the most common index of the protein status of the ruminants (Owen and Zinn, 1988). Hence, the positive $\mathrm{N}$ balance observed in the present study indicated that all diets supplied sufficient $\mathrm{N}$ to the sheep.

\section{Rumen fermentation}

The rumen $\mathrm{pH}$ of sheep fed on different supplements was similar with an average value of 6.8 (Table 5). Similar result was also reported in beef cattle fed RS-based diet supplemented with mulberry leaf pellet (Huyen et al., 2012). 
Steward (1977) suggested that an optimum $\mathrm{pH}$ range of 6.7 to 7.0 for cellulolysis; a $\mathrm{pH}$ below 6.1 could inhibit cellulolysis (Mould et al., 1983). Duran and Kawashima (1980) reported a $\mathrm{pH}$ of greater than 5.7 for optimum MPS. Therefore, the $\mathrm{pH}$ of the rumen of sheep fed with any of the given supplements would not have inhibited either fermentation of fiber or MPS.

Similarly, rumen $\mathrm{NH}_{3}-\mathrm{N}$ (17.8 to $\left.23.0 \mathrm{mg} / \mathrm{dL}\right)$ was also optimal. For optimum rumen microbial growth, Satter and Slyter (1974) recommended minimum concentration of 7 to $8 \mathrm{mg} / \mathrm{dL}$ while Preston and Leng (1987) and Perdok and Leng (1990) suggested higher concentration (10 to 20 $\mathrm{mg} / \mathrm{dL}$ ) for optimum degradation of fibrous feed. The higher rumen $\mathrm{NH}_{3}-\mathrm{N}$ concentration in $\mathrm{T} 2$ and $\mathrm{T} 3$ was due to urea being the supplemental source of $\mathrm{N}$ in the diet. Studies by Mlay et al. (2003) have shown that rumen $\mathrm{NH}_{3}-\mathrm{N}$ concentration was higher when true protein (soy bean cake or casein) was replaced by urea.

Total VFA concentrations were significantly higher for $\mathrm{T} 1$ compared to $\mathrm{T} 2$ and $\mathrm{T} 3$ (Table 5). However, the proportion of acetic acid between $\mathrm{T} 1$ and $\mathrm{T} 2$ was not significantly different. This indicated that acetic acid was predominantly contributed by mulberry and RS fermentation. The degradation of fiber yielded higher amounts of acetic acid due to cellulolytic microbes that fermented fiber (Orskov and Ryle, 1990) from mulberry and RS. Therefore, sheep fed on mulberry (T1) or mulberry partially replaced with urea-rice bran (T2) produce high proportions of acetic acid.

This study showed that the replacement of mulberry with urea-rice bran in T3 decreased the proportions of acetic acid, but increased the proportions of propionic acid. The decrease in acetic acid proportion could be due to a decrease in structural carbohydrate digestion as indicated by the decreased of NDF digestion of T3 (Table 3). Similarly, the decrease in acetic acid proportion was due to addition of corn starch supplementation (Heldt et al., 1999b) or decreased fibrolytic activity attributed by cereal supplementation (Martin et al., 2001).

Starch fermenting microorganisms normally generate relatively higher concentrations of propionic acid (Orskov and Ryle, 1990). Therefore, supplementation of rice bran which contained lower fiber (Table 1) in the T3 diet resulted in a significantly higher proportion of propionic acid. However, the proportion of propionic acid was not affected by the different sources of the rumen degradable $\mathrm{N}$ either from mulberry or urea. The results of acetic acid proportion in rumen was varied. In this study, the proportion of acetic acid of the diet was low (varying from $49.0 \%$ to $58.6 \%$ ), while the value was high $(72 \%)$ as reported by Mlay et al. (2003). The low proportion of acetic acid in the present study was associated with the diets that contained 5\% molasses. The effect of soluble sugar (molasses) on the fermentation pattern was unpredictable than that induced by fiber or starch based diet. This may be related to many types of organisms that utilize glucose directly. Soluble sugars generally give rise to high overall concentrations of VFA in the rumen due to the rapid fermentation rate (Orskov and Ryle, 1990). Based on VFA production, diet T3 was better than diets $\mathrm{T} 1$ and $\mathrm{T} 2$ due to the higher proportion of propionic acid in $\mathrm{T} 3$.

\section{Excretion of purine derivatives and estimation of microbial nitrogen supply}

Excretion of purine derivatives from urine did not differ among treatments. However, MNS was only comparable for T1 and T3 (Table 6). This was probably due to the fermentation ability of $\mathrm{N}$ from mulberry and urea in $\mathrm{T} 1$ and $\mathrm{T} 3$ being similar, as revealed by the similarity of these diets in terms of MNS, efficiency of microbial $\mathrm{N}$ and protein synthesis. It has been previously shown that the source of $\mathrm{N}$ from either urea or true protein had a similar effect on MPS (Herera-Saldana et al., 1990; Oh et al., 1999). On the other hand, Maeng and Baldwin (1976) reported that supplying a mixture of amino acid and peptide further stimulated microbial growth. Results from this study indicated that the different sources of fermentable $\mathrm{N}$ could produce similar microbial protein supply. According to Oh et al. (1999), sheep fed grass silage basal diet had a greater response in terms of MPS when additional dietary starch was supplemented with urea compared to casein. At high starch supplementation, the higher urea supplementation resulted in the higher MPS, while the low starch supplementation produces the high MPS at lower level of casein. Further increases in the level of casein and starch did not increase MPS. This shows that the source of $\mathrm{N}$ was not as crucial as the balancing of energy and protein, as suggested by Owen and Zin (1988) and Hoover and Stokes (1991). Microbial yield has been shown to increase when degradable starch and protein sources were synchronized. In addition, synchronized diets between fast energy and $\mathrm{N}$ release stimulated greater microbial efficiency than that of asynchronous supply (Herera-Saldana et al., 1990).

Energy supplementation in the form of NDF has been shown to yield lower MPS compared to starch, glucose, or starch, glucose and NDF mixed (Hristov et al., 2005). Mulberry has high fermentable $\mathrm{OM}$ and $\mathrm{CP}$, therefore, the comparable microbial protein yield between $\mathrm{T} 1$ and $\mathrm{T} 3$ diets indicated that synchronizing of protein and energy released from mulberry or urea when mixed with rice bran could stimulate MPS. The high N content of the tree fodder and its slow $\mathrm{N}$ release could better match the energy release in fiber fermentation (Van Soest, 1994), thus ensuring synchronization among $\mathrm{N}$ and energy supply for microbial cell synthesis (Hoover and Stokes, 1991). 


\section{CONCLUSION}

Supplementation of mulberry to TRS-based diet at $1.2 \%$ BW or at $32 \%$ of total diet had similar effect to urea rice bran supplementation on the DMI, nutrient digestibility and $\mathrm{N}$ utilization that create efficient of rumen ecosystem and microbial protein supply. Therefore, mulberry supplementation provides fermentable energy and fermentable protein. Mulberry or urea with rice bran offers an alternative source of $\mathrm{N}$ and energy in the diet of sheep fed TRS based diet.

\section{REFERENCES}

AOAC. 1990. Association of Official Analytical Chemist, Official Method of Analysis. 12th Edition. Washington, DC, USA.

Balcells, J., J. A. Guada, J. M. Piero, and D. S. Parker. 1992. Simultaneous determination of allantoin and oxypurines in biological fluids by high-performance liquid chromatography. J. Chromatogr. B. Biomed. Sci. Appl. 575:153-157.

Chen, X. B. and M. J. Gomest. 1992. Estimation of Microbial Protein Supply to Sheep and Cattle Based on Purine Derivatives: An Overview of Technical Details. Occasional publication of International Feed Resources Unit. Rowett Research Institute, Bucksburn, Aberdeen, UK.

Cottyn, B. G. and C. V. Bouque. 1968. Rapid method for the gaschromatographic determination of volatile fatty acids in rumen fluid. J. Agric. Food Chem. 16:105-107.

Durand, M. and R. Kawashima. 1980. Influence of minerals in rumen microbial digestion. In: Digestive Physiology and Metabolism in Ruminants (Eds. Y. Ruckebusch and P. Thivend). MTP Press, Lancaster, UK. pp. 375-408.

Elseed, A. M. A. F. 2004. Performance of sheep offered ammonia, or urea-calcium hydroxide treated rice straw as an only feed. Anim. Sci. J. 75:411-415.

Huyen, N. T., M. Wanapat, and C. Navanukraw. 2012. Effect of mulberry leaf pellet (MUP) supplementation on rumen fermentation and nutrient digestibility in beef cattle fed on rice straw-based diets. Anim. Feed. Sci. Technol. 175:8-15.

Heldt, J. S., R. C. Cochran, G. L. Stokka, C. G. Farmer, C. P. Mathis, E. C. Titgemeyer, and T. G. Nagaraja. 1999a. Effects of different supplemental sugars and starch fed in combination with degradable intake protein on low-quality forage use by beef steers. J. Anim. Sci. 77:2793-2802.

Heldt, J. S., R. C. Cochran, C. P. Mathis, B. C. Woods, K. C. Olson, E. C. Titgemeyer, T. G. Nagaraja, E. S. Vanzant, and D. E. Johnson. 1999b. Effects of level and source of carbohydrate and level of degradable intake protein on intake and digestion low-quality tallgrass-prairie hay by beef steers. J. Anim. Sci. 77:2846-2854.

Herrera-Saldana, R., R. Gomez-Alarcon, M. Torabi, and J. T. Huber. 1990. Influence of synchronizing protein and starch degradation in the rumen on nutrient utilization and microbial protein synthesis. J. Dairy Sci. 73:142-148.

Hoover, W. H. and S. R. Stokes. 1991. Balancing carbohydrates and proteins for optimum rumen microbial yield. J. Dairy Sci. 74:3630-3644.

Hristov, A. N., J. K. Ropp, K. L. Grandeen, S. Abedi, R. P. Etter, A.
Melgar, and A. E. Foley. 2005. Effect of carbohydrate source on ammonia utilization in lactating dairy cow. J. Anim. Sci. 83:408-421.

Kozloski, G. V., M. V. Reffatti, L. M. Bonnecarrere Sanchez, L. D. Lima, L. R. Cadorin Jr, C. J. Harter, and G. Fiorentini. 2007. Intake and digestion by lambs fed a low-quality grass hay supplemented or not with urea, casein or cassava meal. Anim. Feed. Sci. Technol. 136:191-202.

Liu, J. X., A. Susenbeth, and K. H. Sudekum. 2002. In vitro gas production measurements to evaluate interactions between untreated and chemically treated rice straws, grass hay, and mulberry leaves. J. Anim. Sci. 80:517-524.

Liu, J. X., Jun Yao, B. Yana, J. Q. Yu, and Z. Q. Shi. 2001. Effects of mulberry leaves to replace rapeseed meal on performance of sheep feeding on ammoniated rice straw diet. Small Rumin. Res. 39:131-136.

Maeng, W. J. and R. L. Baldwin. 1976. Factors influencing rumen microbial growth rates and yields: Effects of urea and amino acids over time. J. Dairy Sci. 59:643-647.

Martin, C., L. Millet, G. Fonty, and B. Michalet-Doreau. 2001. Cereal supplementation modified the fibrolytic activity but not the structure of the cellulolytic bacterial community associated with rumen solid digesta. Reprod. Nutr. Dev. 41:413-424.

Melaku, S., K. J. Peters, and A. Tegegne. 2004. Intake, digestibility and passage rate in Menz sheep fed tef (Eragrostis tef) straw supplemented with dried leaves of selected multipurpose trees, their mixtures or wheat bran. Small Rumin. Res. 56:139-149.

Mclay, P. S., A. E. Pereka, M. R. Weisbjerg, T. Hvelplund, and J. Madsen. 2003. Digestion and passage kinetics in fiber in mature dairy heifers maintained on poor quality hay as affected by the source and level of nitrogen supplementation. Anim. Feed Sci. Technol. 109:19-33.

Mould, F. L., E. R. Orskov, and S. O. Mann. 1983. Associative effects of mixed feed. I. Effects of type and level of supplementation and the influence of the rumen $\mathrm{pH}$ on cellulolysis in vivo and dry matter digestion of various roughages. Anim. Feed Sci. Technol. 10:15-30.

Oh, Y. G., K. H. Kim, J. H. Kim, J. J. Choung, and D. G. Chamberlain. 1999. The effect of the form of nitrogen in the diet on ruminal fermentation and the yield of microbial protein in sheep consuming diets of grass silage supplemented with starch or sucrose. Anim. Feed Sci. Technol. 78:227-237.

Olson, K. C., R. C. Cochran, T. J. Jones, E. S. Vanzant, E. C. Titgemeyer, and D. E. Johnson. 1999. Effects of ruminal administration of supplemental degradable intake protein and starch on utilization of low-quality warm-season grass hay by beef steers. J. Anim. Sci. 77:1016-1025.

Orskov, E. R. and M. Ryle. 1990. Energy Nutrition in Ruminants. Elsevier Applied Science, London and New York, UK and USA.

Owen, F. N. and R. Zinn. 1988. Protein metabolism of ruminant animals. In: The Ruminant Animal Digestive Physiology and Nutrition. (Ed. D. C. Church). Waveland Press Inc., Prospect Hights, IL, USA. pp. 227-249.

Preston, T. R. and R. A. Leng. 1987. Matching Ruminant Production Systems with Available Resources in The Tropics and Sub-Tropics. Penambul Books, Armidale, New South Wales, Australia. 
Saddul, D., Z. A. Jelan, J. B. Liang, and R. A. Halim. 2005. Evaluation of mulberry (Morus alba) as potential feed supplement for ruminants: The effect of plant maturity on in situ disappearance and in vitro intestinal digestibility of plant fractions. Asian Australas. J. Anim. Sci.18:1569-1574.

SAS. 1989. SAS/STAT User's Guide (Release 6.12) SAS Inst, Inc. Carry, NC, USA.

Satter, L. D. and L. L. Slyter. 1974. Effect of ammonia concentration on rumen microbial protein production in vitro. Br. J. Nutr. 32:199-208.

Silva, T. A. and E. R. Orskov. 1988. The effect of five different supplements on the degradation of straw in sheep given untreated barley straw. Anim. Feed Sci. Technol. 19:289-298.

Stewart, C. S. 1977. Factors affecting the cellulolytic activity of rumen contents. Appl. Environ. Microbiol. 33:497-502.

Van Soest, P. J., J. B. Robertson, and B. A. Lewis. 1991. Methods for dietary fiber, neutral detergent fiber, and nonstarch polysaccharides in relation to animal nutrition. J. Dairy Sci. 74:3583-3593.
Van Soest, P. J. 1994. Nutritional Ecology of Ruminants. 2nd edn. Cornell University Press, Ithaca, NY, USA.

Van Soest, P. J. 2006. Rice straw, the role of silica and treatments to improve quality. Review. Anim. Feed Sci. Technol. 130:137-171.

Yulistiani, D., Z. A. Jelan, J. B. Liang, H. Yaakub, and N. Abdullah. 2007. The use of in vitro gas production technique to evaluate molasses supplementation to mulberry (Morus alba) and rice straw mixed diets. Indonesian J. Anim. Vet. Sci .12:255-261.

Yulistiani, D., Z. A. Jelan, and J. B. Liang. 2008. Degradability of Mulberry (Morus alba) and rice bran in the rumen of sheep fed different diets. Indonesian J. Anim. Vet. Sci. 13:264-272.

Yulistiani, D., Z. A. Jelan, J. B. Liang, and N. Abdullah. 2011. Effect of different supplement on degradation of dry matter and fiber of untreated and urea treated rice straw in the rumen of sheep. J. Indonesian Trop. Anim. Agric. 36:252-259. 